Hammond, S.F., Gajendran, T., Maund, K. and Savage, D.A., 2019. Beyond barriers: Exploring the considerations hindering the adoption of green construction from a behavioural economics perspective. In: Sandanayake, Y.G., Gunatilake, S. and Waidyasekara, A. (eds). Proceedings of the $8^{\text {th }}$ World Construction Symposium, Colombo, Sri Lanka, 8-10 November 2019, pp. 125-136. DOI: doi.org/10.31705/WCS.2019.13. Available at: https://2019.ciobwcs.com/papers

\title{
BEYOND BARRIERS: EXPLORING THE CONSIDERATIONS HINDERING THE ADOPTION OF GREEN CONSTRUCTION FROM A BEHAVIOURAL ECONOMICS PERSPECTIVE
}

\author{
Samuel Fiifi Hammond ${ }^{1}$, Thayaparan Gajendran², Kim Maund ${ }^{3}$ and \\ David A. Savage ${ }^{4}$
}

\begin{abstract}
Several academic researchers have investigated the barriers inhibiting the adoption of green construction. Numerous interventions including raising awareness through educational forums, monitoring and enforcement programmes, and financial incentives have been recommended as strategies to encourage the wider adoption of green construction. However, most of these interventions have failed to address the low adoption of green construction. This raises the question 'Why'? Drawing on the insights from Behavioural Economics, specifically Game Theory and Prospect Theory, and the broad social sciences, it is proposed that it is at the individual level of choice that building construction stakeholders are reluctant to adopt green construction, and building construction stakeholders' decision-making is influenced by the confluence of 'elements' which bring about the tendency for them to prefer non-adoption to adoption. Following this, this paper aimed at exploring the 'considerations' that can underlie the tendency for building construction stakeholders to prefer non-adoption to adoption through a literature review. Four key considerations were found. They are dilemma concern, trust in others' actions, fear of being a sucker, and short-term self-interest. It is concluded that, when given empirical support, policies to increase adoption of green construction should address whichever consideration(s) that strongly hinder green construction adoption in a particular setting.
\end{abstract}

Keywords: Barriers; Behavioural Economics; Decision-Making; Game Theory; Green Construction; Policies; Prospect Theory.

\section{INTRODUCTION}

As a result of the construction industry's huge environmental footprint, 'sustainable construction' was officially proposed in 1994 at the First International Conference on Sustainable Construction (Hill and Bowen, 1997). According to Hill and Bowen (1997),

\footnotetext{
${ }^{1}$ School of Architecture and Built Environment, The University of Newcastle, Australia, samuel.hammond@uon.edu.au

${ }^{2}$ School of Architecture and Built Environment, The University of Newcastle, Australia, thayaparan.gajendran@newcastle.edu.au

${ }^{3}$ School of Architecture and Built Environment, The University of Newcastle, Australia, kim.maund@newcastle.edu.au

${ }^{4}$ Newcastle Business School, The University of Newcastle, Australia, david.savage@newcastle.edu.au
} 
the conference convener proposed that sustainable construction means 'creating a healthy built environment using resource-efficient, ecologically-based principles'. Since then, the terms 'sustainable construction', 'green construction', and 'green building' amongst others are used interchangeably to refer to the pursuance of sustainability in the construction industry (Kibert, 2007). However, Kibert (2007) suggests that 'sustainable building' or 'green building' best describes the product of 'sustainable construction' or 'green construction'. Therefore, in this paper, the term 'green construction' is used and it is defined as the use of healthier and more resource-efficient techniques and materials to deliver a building project.

Even though there is a high-level consensus for the green construction agenda, building construction stakeholders are reluctant to adopt it (Shari and Soebarto, 2014; UN Environment and International Energy Agency, 2017; Dwaikat and Ali, 2018; Yu et al., 2018; Martek et al., 2019). Several countries, both developed and developing have instituted a plethora of policy tools and mechanisms to promote the adoption of green construction, yet, its extensive adoption is lacking. According to Wadu Mesthrige and Kwong (2018), the Hong Kong construction industry is lagging behind in the implementation of green construction despite all the efforts by the government to enhance public awareness, encourage property developers to embrace green building features, and improve green construction standards through a variety of programs. In Hong Kong, there has been considerable effort to promote green construction through a variety of programs for the past 10-15 years (Wadu Mesthrige and Kwong, 2018). Examples of such policy tools include Indoor Air Quality Management Programme and the Hong Kong Building Environmental Assessment Method [HK-BEAM]. In Malaysia, the government has introduced major regulatory and incentive policies to drive forward the green construction agenda (Shari and Soebarto, 2014, Algburi et al., 2016, Zaini and Endut, 2018). Quoting Isa et al. (2018), "the government has introduced major incentives to foster green building investment...in the public and private sectors in Malaysia". However, these policy implementation efforts do not lead to extensive adoption and implementation of green construction in Malaysia (Shari and Soebarto, 2014; Isa et al., 2018; Zaini and Endut, 2018). Zhang et al. (2011c) also questioned why residential developers in China are not adopting green construction in spite of the strong green 'market' environment and the plethora of policy tools and mechanisms. Windapo and Goulding (2015) have also added that the implementation of green construction in South Africa is 'behind the expectations' raised by the legislations enacted to promote it. This misalignment between the high-level consensus and actual behaviour raises the question: why? Consequently, this study seeks to explore the considerations in the decision-making ${ }^{5}$ that will bring about the tendency for building construction stakeholders to prefer non-adoption to adoption even though (a) almost everyone believes green construction is beneficial, and (b) a wide range of policy tools and mechanisms for the promotion of green construction such as educational campaign and financial incentives have been instituted.

Behavioural Economics has provided insights into the drivers of human behaviour. From the perspective of Behavioural Economics, a more representative model of human behaviour takes into consideration a range of factors comprising self-interest, social norms, levels of trust, defaults etc. It has also proven that it is due to the way intervention are framed, the methods through which they are transmitted, and the decision-making

\footnotetext{
${ }^{5}$ It is the individual-level decision-making (see Hammond et al., 2019 for an explanation of the decisionmaking process).
} 
environment, that impact how people respond to them. Applying insights from Behavioural Economics, this study argues that, the choice between non-adoption and adoption is driven by an interacting array element (see section 3). The interaction of these elements complicates issues at the individual level of choice, making building construction stakeholders reluctant to adopt green construction i.e. tend to prefer nonadoption to adoption. From this background, a range of considerations hindering the adoption of green construction, and more importantly drivers of non-adoption are identified through a literature review.

The paper is structured as follows: section two presents a review of the existing literature to provide the background to the study. Section three presents the theoretical foundation of the study. Section four outlines the considerations hindering the adoption of green construction. Section five concludes the paper.

\section{LITERATURE REVIEW}

Several academic studies have investigated the barriers hindering the adoption of green construction. The dominant narrative is that the major barriers hindering the adoption of green construction are lack of awareness and education, lack of regulations and building codes, high cost etc. (see Table 1).

Table 1: Barriers hindering the adoption and implementation of green construction

\begin{tabular}{|c|c|}
\hline Barriers & Supporting references \\
\hline $\begin{array}{l}\text { High cost; lack of awareness and } \\
\text { education; lack of financial } \\
\text { incentives; lack of building codes } \\
\text { and regulations }\end{array}$ & $\begin{array}{l}\text { Zainul Abidin (2010); Zhang et al. (2011a); Zhang et al. } \\
\text { (2011b); Zou and Couani (2012); Djokoto et al. (2014); } \\
\text { Shari and Soebarto (2014); Ametepey et al. (2015a); } \\
\text { Saleh and Alalouch (2015); Chan et al. (2018); Russ et } \\
\text { al. (2018); Wadu Mesthrige and Kwong (2018) }\end{array}$ \\
\hline Lack of demand & Djokoto et al. (2014); Daniel et al. (2018) \\
\hline $\begin{array}{l}\text { Insufficient codes and regulatory } \\
\text { policies from government }\end{array}$ & $\begin{array}{l}\text { Hoffman and Henn (2008); Djokoto et al. (2014); Gluch } \\
\text { et al. (2014); Ametepey et al. (2015a); Ametepey et al. } \\
\text { (2015b); Saleh and Alalouch (2015); Azeem et al. } \\
\text { (2017); Zaini and Endut (2018) }\end{array}$ \\
\hline $\begin{array}{l}\text { Lack of knowledge and } \\
\text { awareness }\end{array}$ & $\begin{array}{l}\text { Choi (2009); Zainul Abidin (2010); Djokoto et al. } \\
\text { (2014); Shari and Soebarto (2014); Zhai et al. (2014); } \\
\text { AlSanad (2015); Ametepey et al. (2015b); Windapo and } \\
\text { Goulding (2015); Saleh and Alalouch (2015); Bohari et } \\
\text { al. (2016); Azeem et al. (2017); Nguyen } \text { et al. (2017); } \\
\text { Wang et al. (2018) }\end{array}$ \\
\hline Lack of financial incentives & $\begin{array}{l}\text { Choi (2009); Zhang et al. (2012); Azeem et al. (2017); } \\
\text { Chan et al. (2018); Wadu Mesthrige and Kwong (2018) }\end{array}$ \\
\hline $\begin{array}{l}\text { Over-discounting the future, } \\
\text { egocentrism, positive illusions, } \\
\text { presumed associations, mythical } \\
\text { fixed-pie, environmental literacy }\end{array}$ & Hoffman and Henn (2008) \\
\hline $\begin{array}{l}\text { Cultural change resistance; lack } \\
\text { of commitment; long payback } \\
\text { periods; tendency to maintain } \\
\text { current practices }\end{array}$ & $\begin{array}{l}\text { Zou and Couani (2012); Ahn et al. (2013); Ametepey et } \\
\text { al. (2015a); Ametepey et al. (2015b) }\end{array}$ \\
\hline
\end{tabular}


Therefore, these studies suggest that educational campaigns and financial incentives will positively impact on the adoption of green construction by increasing awareness, as well as change cognitive assessment of cost and benefits (Olubunmi et al., 2016).

On the contrary, Ofori and Kien (2004) pointed out that, architects in Singapore indicated they are aware of the environmental impacts of buildings and knowledgeable about possible measures which would help avoid these problems. However, they seem to be unable to translate their environmental awareness and knowledge into appropriate design solutions (Ofori and Kien, 2004). Why? Ajzen et al. (2011) conducted four studies that examined the relationship between knowledge and behaviour and concluded that having accurate information about an issue can be irrelevant for behaviour. Kollmuss and Agyeman (2010) also indicated that the question of what influences pro-environmental behaviour is a complex one that cannot be visualized through a single framework. Furthermore, a meta-analysis on factors that have been found to have some influence, positive or negative, on pro-environmental behaviours concluded that $80 \%$ of the factors did not result from knowledge and awareness (Kollmuss and Agyeman, 2010).

Most developers and building owners in Malaysia were concerned about having their buildings built at the minimum cost without giving so much thought about energy efficiency as it was considered an economic waste due to the subsidized electricity tariffs (Shari and Soebarto, 2014). In the same study, the majority of the respondents regarded minimizing the initial capital cost as more important than the long-term operational cost minimization which is a key attribute of green buildings (Shari and Soebarto, 2014). According to Deng et al. (2018), property developers in China claimed there is around $20 \%$ of additional time spent on designing green buildings compared to conventional buildings, and they are not willing to sacrifice such extra time expense. Developers in China also believe that the decision to choose to not do green construction is a safe choice, otherwise, they will incur 'unnecessary' cost which cannot help them be competitive in the market (Zhang et al., 2011c). Perception about complex project delivery process impedes green construction (Zhang et al., 2012). Transaction costs act as a disincentive for developers (Qian et al., 2015). Perception of a sophisticated level of expertise required to fabricate and install green building features hinder its adoption (Li et al., 2014). Ahn et al. (2013) also acknowledged that, long payback periods associated with investing in green buildings act as a deterrent.

$\mathrm{Du}$ Plessis (2007) asserted that, even when technology is available, and an enabling institutional environment has been created, it is a choice to adopt the technologies and make use of the opportunities created. Yet, with a large number of studies investigating why there is less adoption of green construction, all these studies have overlooked the influence of decision-making, and particularly the influence of the individual-level building construction stakeholder decision-making on the adoption of green construction. This is understandable because, the delivery of a building project is a complex process as (a) it involves numerous stakeholders with potentially incompatible concerns, and (b) there are a plethora of procurements methods which determines which of the numerous stakeholders' take overarching decisions with regards to the adoption or non-adoption of green features in a building project. For example, there are instances where a 'green building' has to be requested by a client and this request will be executed by a group of professionals for the client. While in some cases, e.g. real estate development, buildings are ready-made, and consumers just have to purchase. In this case, the decisions to adopt or not adopt green features lies with the professionals involved in the development. 
Therefore, decision-making with regard to the adoption or non-adoption is generally regarded as complex and attributed to the group i.e. group decision processes (Mok et al., 2018). However, it has been shown that it is valuable to study individual-level decisionmaking because groups consist of individuals, which creates a feedback mechanism between the individuals within the group and the group as a unit (Savage, 2018). Also, beliefs that are commonly held by a significant number of individuals becomes the incumbent group belief, which is transmitted back to the group to be adopted by the remaining non-believers (Savage, 2018). It is from this background that, the investigation of the influence of individual building stakeholders' decision-making on the adoption of green construction becomes very important because individual stakeholders form the basis of groups - multiple stakeholders - and directly interact with the environment.

\section{THE INFLUENCE OF INDIVIDUAL-LEVEL DECISION- MAKING ON GREEN CONSTRUCTION ADOPTION}

The achievement of sustainability in the building construction industry, requiring the adoption and implementation of green construction is (a) an action that has a strategic interactive structure because it has an outcome interdependence - outcome depends on the decisions and behaviours of all building construction stakeholders (Geels, 2011); and (b) an action which present a 'present-future' trade-off of cost and benefits - it involves 'giving' time, money, and effort 'today' in return for gains in the 'future'. From this background, Game Theory and Prospect Theory seem well suited as the theoretical lens to use in exploring the considerations hindering the adoption of green construction.

Game Theory describes the behaviour of rational decision-makers (Von Neumann and Morgenstern, 1944, Frey, 2010) who make their decisions based on their expectations of the behaviour of others they are interdependent with i.e. they reason strategically (Osborne and Rubinstein, 1994; Koçkesen, 2007; Samuelson, 2016). Rationality denotes that, individuals choose actions that give the most preferable outcome, given what they expect their opponents to do (Von Neumann and Morgenstern, 1944; Bicchieri and Xiao, 2009; Samuelson, 2016). The important issues that arise from the strategic interactive structure of achieving sustainability are that a building construction stakeholder, for example, a property developer faces the problem of finding an appropriate construction process since his cost and benefits depend on the construction processes of other property developers. The dependence on others' choices makes the decision-making a complex one and justifies the search for strategies that result in Nash equilibrium ${ }^{6}$.

The homo economicus model would predict that individual builders will not shift from conventional construction processes to green construction practices while taking personal losses, even if they individually believe that green practices are much better for the environment and society. The only way that an individual would switch to green construction while maintaining the losses generated by costs would be if the size of the social benefit was much larger than the costs. These behavioural insights come from the predictions of Kahneman and Tversky's (1979) Prospect Theory, which demonstrated that there is an asymmetric function for losses versus gains, such that humans overweigh losses much greater than for gains. A fundamental concept of Prospect Theory is loss aversion - the tendency to prefer avoiding losses to acquiring comparable gains using

\footnotetext{
${ }^{6}$ Nash equilibrium requires that all players choose their strategies optimally given their beliefs, and that all beliefs are consistent with the choices of the opponents (Nash, 1951).
} 
some heuristics (Tversky and Kahneman, 1974; Kahneman et al., 1991; Tversky and Kahneman, 1992). Applied to this study, individual building construction stakeholders are likely to be under the influence of loss aversion because, an outcome framing as losses corresponds to the notion of 'giving' time, money, or effort to do green construction, while an outcome framing as gain corresponds to the benefits associated with adopting green construction. The influence of loss aversion will impact the decision-making process leading to a high tendency for non-adoption. Loss aversion leads to other biases such as status quo bias, regret avoidance, present bias all of which increases the tendency to prefer non-adoption to adoption in the decision-making process.

\section{CONSIDERATIONS HINDERING THE ADOPTION OF GREEN CONSTRUCTION}

Based on the theoretical foundation, it is submitted that there will be an inclination for building construction stakeholders to prefer non-adoption to adoption. From this theoretical conclusion, certain factors (referred to in this study as considerations) will be taken into account in the decision-making. In this section, four key considerations that can be hindering the adoption of green construction are discussed.

\subsection{DILEMMA CONCERN}

Dilemma concern is a concept that describes the degree to which people perceive environmental protection as a social dilemma and follow strategies of conditional cooperation (Franzen, 1995). Dilemma concern is about the extent to which people believe that their actions help to achieve collective goals (Van Lange et al., 1997). Many researchers studying social dilemma have argued that one of the main reasons people do not contribute to public goods is the fact that a single person's actions may have no noticeable effect on the situation (Kollock, 1998). Basically, it is about belief in individual action effectiveness. In this study, dilemma concern refers to the extent to which building construction stakeholders consider that their individual green construction adoption efforts help achieve sustainability and reduce the environmental impacts arising from construction activities. When building construction stakeholders have low dilemma concern, they will believe that their individual action has an impact and help achieve the optimum outcome of sustainability. Hence, they are likely to adopt green construction. However, when they have a high dilemma concern, they will see no need to devote efforts, money and time towards green construction.

Proposition 1: Reducing an individual building stakeholder's 'dilemma concern' will increase the adoption of green construction.

This is dependent on the expectation of overall co-operation from others - trust in others' cooperation (Dawes, 1980, Van Lange et al., 2013). People are more likely to believe that their action can make a significant impact and cooperate if they believe that others also do the same. However, they will choose to non-adopt if they believe others do not adopt, in order to protect themselves from wasting time, money and effort i.e. being a 'sucker'.

\subsection{Trust in Others' ACtions}

This construct suggests that building construction stakeholders' belief about others to be cooperative or uncooperative in the quest for the achievement of sustainability can lead to the decision to adopt or non-adopt green construction. Trust in others' actions as a 
barrier to green construction adoption and implementation originates from the idea of conditional cooperation (Ostrom, 2000). A person may be happy to adopt green construction. But everyone's action will contribute to the best possible outcome. Therefore, if a person does not believe others will adopt, then the best decision is to not adopt as well.

Proposition 2: Increasing an individual building stakeholder 'trust' in other's actions will increase the adoption of green construction.

Trust in others' actions can also emanate from social norms. It has been proffered that, individuals take their cues from what others do and use it as a standard against which to compare their own behaviours (Clapp and McDonnell, 2000; Bicchieri, 2005; Bicchieri and Xiao, 2009; Dolan et al., 2012). According to Dolan et al. (2012), people obtain pleasure from choosing to behave like everyone else, even though this choice may not be maximising overall utility. Thus, social norms can lead to behaviours that are difficult to explain in terms of rationality. In the choice of green construction, 'stories' from other building construction stakeholders may lead others to overestimate or underestimate the 'costs' and 'benefits'. It has been revealed that social trust plays an important role in the decision-making process of green building technologies adoption because, people use trust as a risk reduction strategy (Liu et al., 2018; Rajaee et al., 2019).

\subsection{FEAR OF BEING A SUCKER}

A possible consideration is a fear of being a sucker ('sucker-effect), a fear that others will free ride on one's cooperative actions (Dawes, 1980; Kerr, 1983). From the game theoretic perspective, the highest benefits for an individual is the consequence of everyone behaving cooperatively, while the individual select the non-cooperative choice (Dawes, 1980; Kollock, 1998; Van Lange et al., 2013). The term free-riding generally refers to when an individual wants to benefit from the activities of others without making a fair contribution of one's own. If everyone else chooses to do green construction, the inaction of one individual would not harm the achievement of sustainability. Meanwhile, that individual would receive all the immediate benefits associated with failure to act. Thus, this individual will free ride on the cooperative behaviour of everyone else. This consideration means that people choose to exploit the interdependence situation. Due to a feeling of being exploited by free-riders, one also reduces one's own effort, because he or she does not want to be seen as a sucker who does all the work for his or her colleagues (Mulvey et al., 1998).

Proposition 3: Reducing an individual building stakeholder's 'fear of being a sucker' will increase the adoption of green construction.

Zhang et al. (2011c) found that real estate developers in China believe that, the decision to do green construction is not a safe choice. This is because they will incur 'unnecessary' cost which cannot help them to be competitive in the market. In addition, perceptions of 'lack of demand' is one of the barriers that is widely reported in the literature. If building stakeholders believe that others do not adopt green, everyone will choose to non-adopt, in order to protect themselves from wasting time, money and effort i.e. being a 'sucker'. However, it is likely that they will not think they will incur 'unnecessary cost' or waste time if they believe others also adopt green construction. This consideration will largely depend on the level of dilemma concern. 


\subsection{SHORT-TERM SELF-INTEREST}

The lure of short-term self-interest discourages people from contributing time, money, or effort toward the provision of collectively beneficial goods (Van Lange et al., 2013). Failure to adopt green construction is associated with the immediate benefit. A person will not prefer to exert effort, waste time and spend additional money. It is recognised that green construction involves certain transaction costs (Qian et al., 2015). A sophisticated level of expertise is required to fabricate and install green building features (Li et al., 2014). Self-interest will trigger the tendency to choose non-adoption which will help to circumvent these inherent features of green construction adoption. Profit motive and time is an important element in self-interest. Empirical research on barriers impeding green construction provides evidence for the manifestation of profit motive among building construction stakeholders. According to Choi (2009), people are not interested in green construction because the benefits can only be realised over a lengthy period.

Proposition 4: Reducing an individual building stakeholder's 'propensity for short-term self-interests' will increase the adoption of green construction.

Most developers and building owners in Malaysia consider investment in green buildings as economic waste because, they are concerned about having their buildings built at the minimum cost (Shari and Soebarto, 2014). Similarly, the majority of the respondents regarded minimizing the initial capital cost as more important than the long-term operational cost minimisation which is a key attribute of green buildings (Shari and Soebarto, 2014). Property developers in China claimed there is around $20 \%$ of additional time spent on designing green buildings compared to conventional buildings, and they are not willing to sacrifice such extra time expense (Deng et al., 2018). Likewise, a study by Ahn et al. (2013) in the US found that long payback periods concomitant with investing in green buildings act as a deterrent. A yearning to preserve habits - old ways of doing things will also make people resistant to change behaviour in the face of new ways of doing things.

\section{CONCLUSIONS, IMPLICATIONS FOR POLICY- MAKING AND FURTHER RESEARCH}

Even though there is a high-level consensus for the green construction agenda, building construction stakeholders are reluctant to adopt it. A lot of studies have investigated the barriers hindering the adoption of green construction, and the dominant account is that the major barriers are lack of awareness and education, lack of regulations and building codes, lack of incentive programs etc. Taking a Behavioural Economics perspective, this study has identified four (4) key factors that can be acting as an impediment to the adoption and implementation of green construction: dilemma concern, trust in others' action, fear of being a sucker, and short-term self-interest.

The study makes four propositions that could assist with high-level policy-making. Any policy assisting in reducing an individual building stakeholder's 'dilemma concern', 'fear of being a sucker' and 'propensity for short-term self-interest', while increasing the 'trust in other's actions' will increase the adoption of green construction.

Although the findings of this study have well-founded theoretical support, empirical investigation is required to (a) support, rebut or modify them; and (b) ascertain which of 
them strongly drive green construction non-adoption in a particular setting, so that policies to increase adoption of green construction will address those specific factors.

\section{ACKNOWLEDGEMENT}

This paper is an output of a $\mathrm{PhD}$ research at The University of Newcastle, Australia. We would like to acknowledge The University of Newcastle, Australia for supporting this study with a Higher Degree by Research (HDR) scholarship.

\section{REFERENCES}

Ahn, Y.H., Pearce, A.R., Wang, Y. and Wang, G., 2013. Drivers and barriers of sustainable design and construction: The perception of green building experience. International Journal of Sustainable Building Technology and Urban Development, 4, pp.35-45.

Ajzen, I., Joyce, N., Sheikh, S. and Cote, N.G., 2011. Knowledge and the Prediction of Behavior: The Role of Information Accuracy in the Theory of Planned Behavior. Basic and Applied Social Psychology, 33, pp.101-117.

Algburi, S.M., Faieza, A.A. and Baharudin, B.T.H.T., 2016. Review of green building index in Malaysia; existing work and challenges. International Journal of Applied Engineering Research, 11, pp.31603167.

Alsanad, S., 2015. Awareness, Drivers, Actions, and Barriers of Sustainable Construction in Kuwait. Procedia Engineering, 118, pp.969-983.

Ametepey, O., Aigbavboa, C. and Ansah, K., 2015a. Barriers to Successful Implementation of Sustainable Construction in the Ghanaian Construction Industry. Procedia Manufacturing, 3, pp.1682-1689.

Ametepey, S.O., Gyadu-Asiedu, W. and Assah-Kissiedu, M., 2015b. Sustainable Construction Implementation in Ghana: Focusing on Awareness and Challenges. Civil and Environmental Research, 7, pp.109-119.

Azeem, S., Naeem, M.A., Waheed, A. and Thaheem, M.J., 2017. Examining barriers and measures to promote the adoption of green building practices in Pakistan. Smart and Sustainable Built Environment, 6, pp.86-100.

Bicchieri, C., 2005. The Grammar of Society: The Nature and Dynamics of Social Norms: Cambridge University Press.

Bicchieri, C. and Xiao, E., 2009. Do the right thing: But only if others do so. Journal of Behavioral Decision Making, 22, pp.191-208.

Bohari, A.a.M., Skitmore, M., Xia, B. and Zhang, X., 2016. Insights into the adoption of green construction in Malaysia: The drivers and challenges. 7th Asia-Pacific International Conference on EnvironmentBehaviour Studies. St Leonard Hall, Edinburgh University, United Kingdom: e-International Publishing House, Ltd., pp.45-53.

Chan, A.P.C., Darko, A., Olanipekun, A.O. and Ameyaw, E.E., 2018. Critical barriers to green building technologies adoption in developing countries: The case of Ghana. Journal of Cleaner Production, 172, pp.1067-1079.

Choi, C., 2009. Removing Market Barriers to Green Development: Principles and Action Projects to Promote Widespread Adoption of Green Development Practices. Journal of Sustainable Real Estate, 1, pp.107-138.

Clapp, J.D. and Mcdonnell, A.L., 2000. The relationship of perceptions of alcohol promotion and peer drinking norms to alcohol problems reported by college students. Journal of College Student Development, 41, pp.19-26.

Daniel, E.I., Oshineye, O. and Oshodi, O., 2018. Barriers to sustainable construction practice in Nigeria. In: C. Gorse and C.J. Neilson, eds. $34^{\text {th }}$ Annual Association of Researchers in Construction Management Conference, ARCOM 2018, Association of Researchers in Construction Management, pp.149-158.

Dawes, R.M., 1980. Social Dilemmas. Annual Review of Psychology, 31, pp.169-193. 
Deng, W., Yang, T., Tang, L. and Tang, Y.-T., 2018. Barriers and policy recommendations for developing green buildings from local government perspective: a case study of Ningbo China. Intelligent Buildings International, 10, pp.61-77.

Djokoto, S.D., Dadzie, J. and Ohemeng-Ababio, E., 2014. Barriers to sustainable construction in the Ghanaian construction industry: consultants perspectives. Journal of Sustainable Development, 7(1), p.134.

Dolan, P., Hallsworth, M., Halpern, D., King, D., Metcalfe, R. and Vlaev, I., 2012. Influencing behaviour: The mindspace way. Journal of Economic Psychology, 33, pp.264-277.

Du Plessis, C., 2007. A strategic framework for sustainable construction in developing countries. Construction Management and Economics, 25, pp.67-76.

Dwaikat, L.N. and Ali, K.N., 2018. The economic benefits of a green building - Evidence from Malaysia. Journal of Building Engineering, 18, pp.448-453.

Franzen, A., 1995. Group Size 'and One-Shot Collective Action. Rationality and Society, 7, pp.183-200.

Frey, E., 2010. Evolutionary game theory: Theoretical concepts and applications to microbial communities. Physica A: Statistical Mechanics and its Applications, 389, pp.4265-4298.

Geels, F.W., 2011. The multi-level perspective on sustainability transitions: Responses to seven criticisms. Environmental Innovation and Societal Transitions, 1, pp.24-40.

Gluch, P., Gustafsson, M., Thuvander, L. and Baumann, H., 2014. Charting corporate greening: environmental management trends in Sweden. Building Research and Information, 42, pp.318-329.

Hammond, S.F., Savage, D.A., Gajendran, T. and Maund, K. 2019. Stakeholders Embrace Green Construction as the Right Direction: But as Individuals they make Self-Interested Decisions. CIB World Building Congress 2019. Hong Kong Polytechnic University, Hong Kong.

Hill, R.C. and Bowen, P.A., 1997. Sustainable construction: principles and a framework for attainment. Construction Management and Economics, 15, pp.223-239.

Hoffman, A.J. and Henn, R., 2008. Overcoming the Social and Psychological Barriers to Green Building. Organization and Environment, 21, pp.390-419.

Isa, N.K.M., Yunos, M.Y.M., Ibrahim, M.H., Ismail, K. and Marzuki, M., 2018. An exploration of drivers and strategies for encouraging the delivery of green building projects in housing development. International Journal of Technology, 9, pp.1702-1714.

Kahneman, D., Knetsch, J.L. and Thaler, R.H., 1991. Anomalies: The Endowment Effect, Loss Aversion, and Status Quo Bias. The Journal of Economic Perspectives, 5, pp.193-206.

Kahneman, D. and Tversky, A., 1979. Prospect Theory: An Analysis of Decision under Risk. Econometrica, 47, pp.263-291.

Kerr, N.L., 1983. Motivation losses in small groups: A social dilemma analysis. Journal of Personality and Social Psychology, 45, pp.819-828.

Kibert, C.J., 2007. The next generation of sustainable construction. Building Research and Information, 35, pp.595-601.

Koçkesen, L., 2007. Unobservable Contracts as Precommitments. Economic Theory, 31, pp.539-552.

Kollmuss, A. and Agyeman, J., 2010. Mind the Gap: Why do people act environmentally and what are the barriers to pro-environmental behavior? Environmental Education Research, 8, pp.239-260.

Kollock, P., 1998. Social dilemmas: The anatomy of cooperation. Annual Review of Sociology, 24(1), pp.183-214.

Li, Y., Yang, L., He, B. and Zhao, D., 2014. Green building in China: Needs great promotion. Sustainable Cities and Society, 11, pp.1-6.

Liu, Y., Hong, Z., Zhu, J., Yan, J., Qi, J. and Liu, P., 2018. Promoting green residential buildings: Residents' environmental attitude, subjective knowledge, and social trust matter. Energy Policy, 112, pp.152-161.

Martek, I., Hosseini, M.R., Shrestha, A., Edwards, D.J. and Durdyev, S., 2019. Barriers inhibiting the transition to sustainability within the Australian construction industry: An investigation of technical and social interactions. Journal of Cleaner Production, 211, pp.281-292. 
Mok, K.Y., Shen, G.Q. and Yang, R., 2018. Stakeholder complexity in large scale green building projects: A holistic analysis towards a better understanding. Engineering, Construction and Architectural Management, 25, pp.1454-1474.

Mulvey, P.W., Bowes-Sperry, L. and Klein, H.J., 1998. The Effects of Perceived Loafing and Defensive Impression Management on Group Effectiveness. Small Group Research, 29, pp.394-415.

Nguyen, H.D., Nguyen, L.D., Chih, Y.Y. and Le-Hoai, L., 2017. Influence of participants' characteristics on sustainable building practices in emerging economies: Empirical case study. Journal of Construction Engineering and Management, 143(8), p.05017014.

Ofori, G. and Kien, H.L., 2004. Translating Singapore architects' environmental awareness into decision making. Building Research and Information, 32, pp.27-37.

Olubunmi, O.A., Xia, P.B. and Skitmore, M., 2016. Green building incentives: A review. Renewable and Sustainable Energy Reviews, 59, pp.1611-1621.

Osborne, M.J. and Rubinstein, A., 1994. A Course in Game Theory: MIT Press.

Ostrom, E., 2000. Collective Action and the Evolution of Social Norms. The Journal of Economic Perspectives, 14, pp.137-158.

Qian, Q., Chan, E. and Khalid, A., 2015. Challenges in Delivering Green Building Projects: Unearthing the Transaction Costs (TCs). Sustainability, 7, pp.3615-3636.

Rajaee, M., Hoseini, S.M. and Malekmohammadi, I., 2019. Proposing a socio-psychological model for adopting green building technologies: A case study from Iran. Sustainable Cities and Society, 45, pp.657-668.

Russ, N.M., Hanid, M. and Ye, K.M., 2018. Literature review on green cost premium elements of sustainable building construction. International Journal of Technology, 9, pp.1715-1725.

Saleh, M.S. and Alalouch, C., 2015. Towards Sustainable Construction in Oman: Challenges and Opportunities. Procedia Engineering, 118, pp.177-184.

Samuelson, L., 2016. Game Theory in Economics and Beyond. Journal of Economic Perspectives, 30, pp.107-130.

Savage, D.A., 2018. Towards a Complex Model of Disaster Behaviour. Australia: University of Newcastle, $1-2$.

Shari, Z. and Soebarto, V., 2014. Investigating sustainable practices in the Malaysian office building developments. Construction Innovation, 14, pp.17-35.

Tversky, A. and Kahneman, D., 1974. Judgment under Uncertainty: Heuristics and Biases. Science, 185, pp.1124-1131.

Tversky, A. and Kahneman, D., 1992. Advances in prospect theory: Cumulative representation of uncertainty. Journal of Risk and Uncertainty, 5, pp.297-323.

Un Environment and International Energy Agency, 2017. Towards a zero-emission, efficient, and resilient buildings and construction sector.

Van Lange, P.a.M., De Bruin, E.M.N., Otten, W. and Joireman, J.A., 1997. Development of prosocial, individualistic, and competitive orientations: Theory and preliminary evidence. Journal of Personality and Social Psychology, 73, pp.733-746.

Van Lange, P.a.M., Joireman, J., Parks, C.D. and Van Dijk, E., 2013. The psychology of social dilemmas: A review. Organizational Behavior and Human Decision Processes, 120, pp.125-141.

Von Neumann, J. and Morgenstern, O., 1944. Theory of games and economic behavior Princeton, NJ, US: Princeton University Press.

Wadu Mesthrige, J. and Kwong, H.Y., 2018. Criteria and barriers for the application of green building features in Hong Kong. Smart and Sustainable Built Environment, 7(3/4), pp.251-276.

Wang, W., Zhang, S., Su, Y. and Deng, X., 2018. Key Factors to Green Building Technologies Adoption in Developing Countries: The Perspective of Chinese Designers. Sustainability, 10(11), p.4135.

Windapo, A.O. and Goulding, J.S., 2015. Understanding the gap between green building practice and legislation requirements in South Africa. Smart and Sustainable Built Environment, 4, pp.67-96.

Yu, T., Shi, Q., Zuo, J. and Chen, R., 2018. Critical factors for implementing sustainable construction practice in HOPSCA projects: A case study in China. Sustainable Cities and Society, 37, pp.93-103. 
Zaini, A.A. and Endut, I.R., 2018. Major challenges in implementing green construction. Journal of Engineering and Applied Sciences, 13, pp.8865-8869.

Zainul Abidin, N., 2010. Investigating the awareness and application of sustainable construction concept by Malaysian developers. Habitat International, 34, pp.421-426.

Zhai, X., Reed, R. and Mills, A., 2014. Addressing sustainable challenges in China: The contribution of off-site industrialisation. Smart and Sustainable Built Environment, 3, pp.261-274.

Zhang, X., Platten, A. and Shen, L., 2011a. Green property development practice in China: Costs and barriers. Building and Environment, 46, pp.2153-2160.

Zhang, X., Shen, L., Tam, V.W.Y. and Lee, W.W.Y., 2012. Barriers to implement extensive green roof systems: A Hong Kong study. Renewable and Sustainable Energy Reviews, 16, pp.314-319.

Zhang, X., Shen, L. and Wu, Y., 2011b. Green strategy for gaining competitive advantage in housing development: a China study. Journal of Cleaner Production, 19, pp.157-167.

Zhang, X., Shen, L., Wu, Y. and Qi, G., 2011c. Barriers to Implement Green Strategy in the Process of Developing Real Estate Projects. The Open Waste Management Journal, 4, pp.33-37.

Zou, P.X.W. and Couani, P., 2012. Managing risks in green building supply chain. Architectural Engineering and Design Management, 8, pp.143-158. 